\author{
Plant-derived vaccines \\ Aybüke OKAY ${ }^{1}$, Semra AYDIN ${ }^{* 1}$, İlker BÜYÜK², Emine Sümer ARAS ${ }^{2}$ \\ ORCID: 0000-0002-6772-4316; 0000-0002-1670-9677; 0000-0002-0843-8299; 0000-0003-3474-9493 \\ ${ }^{1}$ Hacettepe University, Vaccine Institute, 06100 Ankara, Turkey \\ ${ }^{2}$ Ankara University, Faculty of Science, Department of Biology, 06100 Ankara, Turkey
}

\begin{abstract}
Plants are platforms where recombinant proteins and other biopharmaceuticals can be produced easily, cheaply and safely and can be purified back. Recently, many recombinant proteins such as growth hormone, antibody milk proteins, serum albumin and various industrial enzymes produced in bacterial or mammalian cell cultures have been produced in plant tissue or in plant cell culture. Plant tissues provide suitable post-translational modifications for production of recombinant viral and bacterial antigens and show the same biological activity as the recombinant vaccines produced in microorganisms. All of these have paved the way for their usage in vaccine production. Production of recombinant protein in plants requires stable or transient integration of target gene sequence depending on the location in the plant cell. While the biolistic method is used for the stable transformation of the target gene in the nucleus or chloroplast, plant pathogen Agrobacterium sp. mediated gene transfer method is used for transient gene transfer. Plant system are extremely suitable expression vectors for industrial production of pharmaceutical proteins, with their proven production capacity and economic feasibility.
\end{abstract}

Keywords: plant derived vaccines, genetic modification, plant biotechnology

\title{
Bitkisel türevli aşılar
}

\section{Özet}

Bitkiler, rekombinant proteinlerin ve diğer biyofarmasotiklerin kolay, ucuz ve güvenli üretiminin sağlanabildiği ve geri saflaştırılabildiği platformlardır. Günümüzde bakteri ya da memeli hücre kültürlerinde üretilen büyüme hormonu, antikor süt proteinleri, serum albumini ve çeşitli endüstriyel enzimler gibi birçok rekombinant proteinin bitkisel dokuda ya da bitki hücre kültüründe üretimi gerçekleştirilmiştir. Bitkisel dokuların rekombinant viral ve bakteriyel antijenlerin üretimleri için uygun post-translasyonel modifikasyonları sağlamaları ve mikroorganizmalarda üretilen rekombinant aşılar ile aynı biyolojik aktiviteyi göstermeleri, aşı üretiminde kullanılmalarının önünü açmıştır. Bitkisel rekombinant protein üretimi, hedef gen dizisinin bitki hücresindeki konumuna bağlı olarak stabil veya geçici entegrasyonunu gerektirir. Biyolistik yöntemi, hedef genin çekirdek veya kloroplasta stabil transformasyonu için kullanılırken, bir bitki patojeni olan Agrobacterium sp. aracılı gen transferi yöntemi, geçici ve stabil gen transferi için kullanılmaktadır. Bitkisel sistemler kanıtlanmış üretim kapasiteleri ve ekonomik fizibiliteleri ile farmasötik proteinlerin endüstriyel boyutta üretimleri için son derece uygun ekspresyon vektörleridir.

Anahtar kelimeler: bitkisel aşılar, genetik modifikasyon, bitki biyoteknolojisi

\footnotetext{
${ }^{*}$ Corresponding author / Haberleşmeden sorumlu yazar: Tel.: +903123053494; Fax.: +903123053493; E-mail:semra.aydin@ hacettepe.edu.tr

(C) Copyright 2021 by Biological Diversity and Conservation Geliş tarihi: 01.01.2021; Yayın tarihi: 15.04.2021 


\section{Giriş}

Aşı, bir hastalığa karşı spesifik koruma sağlamak amacıyla hazırlanmış immuno-biyolojik bir materyaldir ve hastalıklara karşı immünizasyon sağlayarak morbidite ve mortaliteyi azaltmak amacıyla kullanılır. Çocuk ve genç yetişkin ölümlerine sebep olan çiçek hastalığı, tüberküloz, zatürre, kızamık, kızamıkçı, hepatit A-B, menenjit, grip, difteri, boğmaca ve tifo gibi bulaşıcı hastalıkların eradikasyonunda aşılamanın büyük rolü bulunmaktadır [1]. Dünya genelinde uygulanan yaygın aşılama çalışmaları çocuk felci (poliomiyelit) vakalarının azalmasını sağlamış, ülkemizde de doğru aşılama politikaları sayesinde Sağlık Bakanlığı verilerine göre son 19 yılda çocuk felci vakasına rastlanmamıştır. Doğru aşılama politikalarının uygulanmasıyla birlikte ülkemizde son 16 yılda sadece tek difteri ve buna bağlı ölüm vakası tespit edilmiştir. Dünya Sağlık Örgütü 2016 verilerine göre aşı kararsızlığı/reddi kavramının ortaya çıkmasıyla birlikte kızamık vaka sayılarının arttığı bildirilmiştir. 2017 yılında Türkiye'de 25 tetanoz vakası gözlenmiş ve bu vakaların tamamının aşısız olduğu anlaşılmıştır. Bu sonuçlar etkin ve kapsayıcı aşılama çalışmaları ile hastalıkların görülme sıklığının oldukça azalabildiğini bir kez daha göstermiştir. Dünya Sağlık Örgütü (WHO) raporlarına göre aşılama ile yılda 2,5 milyondan fazla yaşam kurtarılmaktadır [2]. 18. yüzyılda başlayan aşı üretimi, sonrasında kapsamlı mikrobiyolojik ve immünolojik çalışmalar, klinik araştırmalar, sterilizasyon ve güvenlik standartlarının düzenlenmesiyle giderek şekillenmiş ve aşı bilimi gün geçtikçe değerlenmiş ve gelişmiştir. Günümüzde aşı üretimi, ürün kalitesinin yaşamsal öneme sahip olduğu ve sürekli olarak istenilen kalitede ürün üretebilme becerisinin vazgeçilmez olduğu bir endüstridir. Bireylerin sağlı̆̆ını riske sokmayacak şekilde güvenilir, kaliteli ve etkin aşıların üretimi zorunluluk arz etmektedir [3]. Farklı şekillerde etki gösteren üç ana aşı tipi bulunmaktadır: Canlı (zayıflatılmış) aşılar, inaktif aşılar ve alt birim aşılar (rekombinant, konjugat, toksoid ve polisakkarit aşıları). Canlı aşılarla, vücuda bir hastalığa neden olan mikrop veya virüsün zayıflatılmış bir versiyonu enjekte edilmektedir. Kızamık, kabakulak ve kızamıç̧ı (MMR kombine aşı), rotavirüs, çiçek hastalığı, suçiçeği ve sarıhumma aşıları, canlı aşılara örnek olarak verilebilir [3]. İnaktif aşılar ise 1sı veya kimyasallarla öldürülen bir bakteri veya virüs türünün kullanıldı̆̆ aşılardır. Hepatit A, grip, çocuk felci ve kuduz aşıları inaktif aşılardır. Alt birim, rekombinant, konjugat ve polisakkarit aşılar ise mikrop veya virüsün belirli kısımlarının kullanılmasıyla elde edilen aşılardır. Vücutta çok güçlü bağışıklık tepkilerini tetikleyebilirler. Hib (Hemophilus influenza tip b), hepatit B, insan papilloma virüsü (HPV), boğmaca, pnömokok hastalığı, menigokokal hastalık ve zona aşıları bu gruba örnek olarak verilebilir [4]. Alt birim aşılarda, bir mikroorganizma veya virüsten oluşturdukları bağışıklık tepkisinin gücüne göre seçilen spesifik antijenler izole edilir. Rekombinant aşılar, genetik mühendisliği yoluyla üretilmektedir. Konjuge aşılar, hastalığa neden olacak ya da vücutta bir bağışıklık tepkisi oluşturacak kadar güçlü olmayan bakteri veya virüsten antijenik nitelikte parçalar kullanmaktadır. Polisakkarit aşılar, bir bakteri veya virüsün dış kılıfından şeker moleküllerini (polisakkaritler olarak bilinir) kullanmaktadır. Bu şeker molekülleri kimyasal olarak taşıyıcı proteinlere bağlıdır ve konjuge aşılara benzer şekilde çalışmaktadır. Toksoid aşılarda ise, bakterinin veya virüsün tamamına değil hastalığa neden olan bakteri veya virüsün belirli kısımlarına karşı bağışıklık oluşturmak için bakteri veya virüs tarafından oluşturulan toksinlerinden yararlanılır [5].

\subsection{Bitkilerde Aşı Üretiminin Tarihçesi}

Bitki genetik mühendisliğinin gelişmesi ile birlikte bilim dünyasına giren transgenik (genetiği değiştirilmiş) bitkiler başlangıçta tarımsal kapasitenin artırılması amacıyla kullanılmışlardır. Ancak son yıllarda farmasötik ve veterinerlik ile ilgili birçok endüstri kolunda büyük ölçekli protein üretiminde kullanımlarının yaygınlaştığ 1 görülmektedir. Proteinlerin ve diğer biyofarmasötiklerin bitkisel dokularda kolay, ucuz ve güvenli bir şekilde üretilebilmesi ilaç endüstrisi açısından önemli bir keşiftir. Bitki hücreleri, rekombinant proteinlerin güvenli üretiminin kolaylıkla sağlanabildiği ve kolay bir şekilde geri saflaştırılabildiği, 30 yılı aşkın süredir kullanılan köklü bir teknoloji platformudur. Günümüzde bakteri ya da memeli hücre kültürlerinde üretilen büyüme hormonu, antikor süt proteinleri, serum albumini ve çeşitli endüstriyel enzimler gibi birçok rekombinant proteinin endüstriyel amaçlı bitki dokusunda ya da bitki hücre kültüründe üretimi gerçekleştirilmiştir [6-11]. Ayrıca hali hazırda ticarileştirilmiş birçok enzim ve reaktiflerin üretimlerinde yine bitkisel üretim sistemleri kullanılmaktadır. Örneğin; mısırda üretilen sı̆̆ır tripsini (TrypZean Sigma-Aldrich) 2002 yılından beri ticari olarak erişilebilir durumdadır. 2014 yılında ise tütün bitkisinde insan tip I kollajeninin üretimi sağlanmıştır. Çeltikle (Oryza sp.) üretilen insan lizozimi ve laktoferrin ise ticarileşmiş diğer ürünlerdendir. İsrail Firması Protalix, tütün ve havuç bitkisinde biyofarmasotiklerin üretimi için çeşitli metotlar geliştirmiş ve söz konusu firmanın Gaucher hastalığının tedavisinde kullanılan bitkisel taligluseraz alfa etken maddesi FDA tarafından ruhsatlanmıştır [6]. Dünyanın daha fakir olan ülkelerinde yetersiz sağlık altyapıları, aşının maliyeti ve soğutma sistemlerinin eksikliğinin aşı kullanımını sınırladığı ve bu durumun söz konusu ülkelerde halen ölümlerin en önemli sebebi olduğu görülmektedir. 1992 yılında bu soruna çözüm bulabilmek amacı ile Dünya Sağlık Örgütü ve bazı gönüllü kuruluşların işbirliği ile kurulan 'Çocuk Aşı Girişimi (Children's Vaccine Initiative)' daha ucuz ve taşıma problemi olmayan aşı üretim teknolojilerinin keşfini ve küresel düzeyde alternatif immünizasyon programlarının oluşturulmasını görev edinmiştir. Bitkisel dokuda üretimin nispeten kolay ve ucuz olması, rekombinant viral ve bakteriyel antijenlerin üretimleri için uygun post-translasyonel modifikasyonları sağlamaları ve mikroorganizmalarda üretilen rekombinant aşılar ile aynı biyolojik aktiviteyi göstermeleri, bitkisel dokuların aşı üretiminde kullanılma 
çalışmalarını teşvik eden önemli gerekçelerdir [7]. Yenilebilir aşı kavramı, transgenik bitkilerin yenilebilir dokularının kullanıldığı alt birim aşılar için bir üretim sistemi olarak tasarlanmıştır. Yapılan çalışmalarda bitkisel kökenli bir aşının insanlarda güvenli bir şekilde, bağışıklık tepkisi oluşturabileceği gösterilmiştir. Özellikle aşıya erişimde maliyeti artıran soğuk zincir koşullarının gerekliliğini ortadan kaldırması sebebi ile de yenilebilir aşılar dikkat çekmiştir. Bu konuda yapılan çalışmalarda ilk zamanlar, bitkisel ekspresyon sistemlerinin rekombinant protein üretim verimlerinin bakteri ve memeli hücre kültürlerine kıyasla düşük olduğu tespit edilmiştir. Nicotiana benthamiana yapraklarından 2 g/kg'a kadar rekombinant antikor verimi sağlanabilirken, memeli hücre kültürlerinde verimin 5-10 g/L'lik olduğu gösterilmiştir [8]. $\mathrm{Bu}$ sebeple bitkilerde verimi artırabilmek amacı ile kültür ortamının modifikasyonu vb. çeşitli yöntemler denenmiş, üretilen proteinin, bitki apoplastından hücre bozulması olmaksızın kültür ortamına salınımı ve saflaştırılması sağlanmıştır. Bitki çekirdek ve kloroplast dokusunda eksprese edilen antijenik proteinlerin deney hayvanlarında bağ 1 şıklık yanıtı oluşturduğu çeşitli araştırmalarda kanıtlanmıştır [9]. Bitkisel türevli Newcastle hastalığı virüsü (NDV) aşısı, 2006 yılında Amerika Birleşik Devletleri Tarım Bakanlığı'ndan ruhsatlanmıştır. Bitkisel ekspresyon sistemleri, hem beşeri hem de veteriner aşılar açısından umut vaat etmektedir. Bu sebepledir ki son yıllarda, stabil ve geçici transformasyon yöntemleri kullanılarak tütün (Nicotiana tabacum), domates (Solanum lycopersicum), Arabidopsis thaliana, mısır (Zea mays), çeltik gibi çok çeşitli bitkilerde antijenik proteinlerin üretimleri konusunda ilerleme kaydedilmektedir. Çeşitli araştırmalarda üretilen rekombinant proteinler Tablo 1 de özetlenmiştir [10-36]. Bu çalışmalar, gelecekte bitki türevi farmasötik proteinlerin, klinik geliştirme aşamasında ve sonrasında ticari pazarda yerlerini alması için umut vaat etmektedir.

Tablo 1. Bitkisel türevli aşı üretim çalışmaları

\begin{tabular}{|c|c|c|c|}
\hline \multirow[t]{2}{*}{ Patojen/Hastalık } & \multirow[t]{2}{*}{ Bitki } & \multicolumn{2}{|l|}{ Transform } \\
\hline & & asyon Metodu & eferans \\
\hline Hepatit B virüsü & Tütün (Nicotiana tabacum) & Agrobacterium aracilı & {$[10]$} \\
\hline Aktarılabilir gastroenterit virüs (TGEV) & Tütün (Nicotiana tabacum) & Agrobacterium aracilı & [11] \\
\hline Rinderpest virus (RPV) & Fistık (Arachis hypogea L.) & Agrobacterium aracilı & {$[12]$} \\
\hline Sığır uçuğu virüsü & Tütün (Nicotiana tabacum) & Mekanik aşılama & {$[13]$} \\
\hline İnsan papilloma virüsü & Tütün (Nicotiana tabacum) & Agrobacterium arac1lı & {$[14]$} \\
\hline Aktarılabilir gastroenterit virüs (TGEV) & Misir (Zea mays) & Agrobacterium aracilı & {$[15]$} \\
\hline Bulaşıcı bronşit virüsü (IBV) & Patates (Solanum tuberosum) & Agrobacterium aracilı & [16] \\
\hline Şarbon & Tütün (Nicotiana tabacum) & Biyolistik yöntem & {$[17]$} \\
\hline Hepatit B virüsü (HBV) & Patates (Solanum tuberosum) & Agrobacterium aracilı & {$[18]$} \\
\hline Newcastle hastalığı virüs (NDV) & Misir (Zea mays) & Biyolistik yöntem & [19] \\
\hline Enterotoksijenik E. coli & Yonca (Medicago sativa L.) & Agrobacterium aracilı & {$[20]$} \\
\hline Cottontail tavşan papilloma virüsü & Tütün (Nicotiana tabacum) & Agrobacterium aracilı & {$[21]$} \\
\hline Bulaşıcı bursal hastalık virüsü (IBDV) & Çeltik (O. sativa) & Agrobacterium aracilı & {$[22]$} \\
\hline Hepatit B virüsü (HBV) & Tütün (Nicotiana tabacum) & Agrobacterium aracilı & {$[23]$} \\
\hline $\begin{array}{l}\text { H5N1 (kuş grip virüsü) \& H1N1 (insan) } \\
\text { influenza suşları }\end{array}$ & Tütün (Nicotiana tabacum) & Agrobacterium aracılı & {$[24]$} \\
\hline Enterotoxigenic E. coli & Havuç (Daucus carota) & Agrobacterium aracilı & {$[25]$} \\
\hline Norwalk virus & Tütün (Nicotiana tabacum) & Agrobacterium aracilı & {$[26]$} \\
\hline Kuş gribi (H5N1) & Tütün (Nicotiana tabacum) & Agrobacterium aracilı & [27] \\
\hline Grip virüsü & Tütün (Nicotiana tabacum) & Agrobacterium aracilı & {$[28]$} \\
\hline Kuş gribi (H5N1) & Su mercimeği (Lemna minör) & Agrobacterium aracilı & [29] \\
\hline Kanser (tümör işaretleyici) & Tütün (Nicotiana tabacum) & Agrobacterium aracilı & {$[30]$} \\
\hline Kanser (tümör işaretleyici) & Çeltik (Oryza sativa) & Biyolistik yöntem & [31] \\
\hline Kanser (tümör işaretleyici) & $\begin{array}{l}\text { Tahil bitkileri (Triticum, Oryza } \\
\text { sativa) }\end{array}$ & Biyolistik yöntem & {$[32]$} \\
\hline İnsan kolorektal kanseri & Tütün (Nicotiana tabacum) & Agrobacterium aracilı & {$[33]$} \\
\hline HIV & Tütün (Nicotiana tabacum) & Agrobacterium aracilı & {$[34]$} \\
\hline Ebola virus & Tütün (Nicotiana tabacum) & Agrobacterium aracilı & {$[35]$} \\
\hline Ebola virus & Marul (L. sativa) & Agrobacterium aracilı & {$[36]$} \\
\hline
\end{tabular}

\subsection{Bitkilerde Aşı Üretimi İçin Kullanılan Stratejiler}

Bitkisel türevli aşı üretimi amacıyla kullanılabilecek çok sayıda yöntem mevcuttur. Aşı/antijen üretimi, seçilen hedef gen dizisinin bitki hücresinde yerleştirildiği konuma bağlı olarak stabil veya geçici entegrasyonunu gerektirir. $\mathrm{Bu}$ amaçla aracı olarak çeşitli plazmit vektörler, bakteriler veya bitkisel patojenler kullanılabilir. Geçici transformasyon sisteminde ise heterolog gen, konakçı hücrelerde geçici süre kaldıktan hemen sonra istenen protein veya antijenin üretimi gerçekleşir. Stabil transformasyon sisteminde ise, hedef genin bitki çekirdek veya kloroplastına 
entegrasyonu sağlanır. Bu adlandırma aktarılan gen dizisinin, bitki hücrelerinin genetiğinde meydana getirdiği kalıcı değişikliklerden ileri gelmektedir. Biyolistik yöntemi istenilen genin stabil transformasyonu için kullanılırken, bir bitki patojeni olan Agrobacterium sp. aracılı gen transferi, geçici ve stabil gen transferi için kullanılan bir yöntemdir. Bu yöntem ile elde edilen stabil transgenik bitkilerde nisbeten düşük oranda alt birim antijen üretimi sağlanabilir (toplam çözünebilir bitki protein oranının maksimum \%0.3’ü) [37].

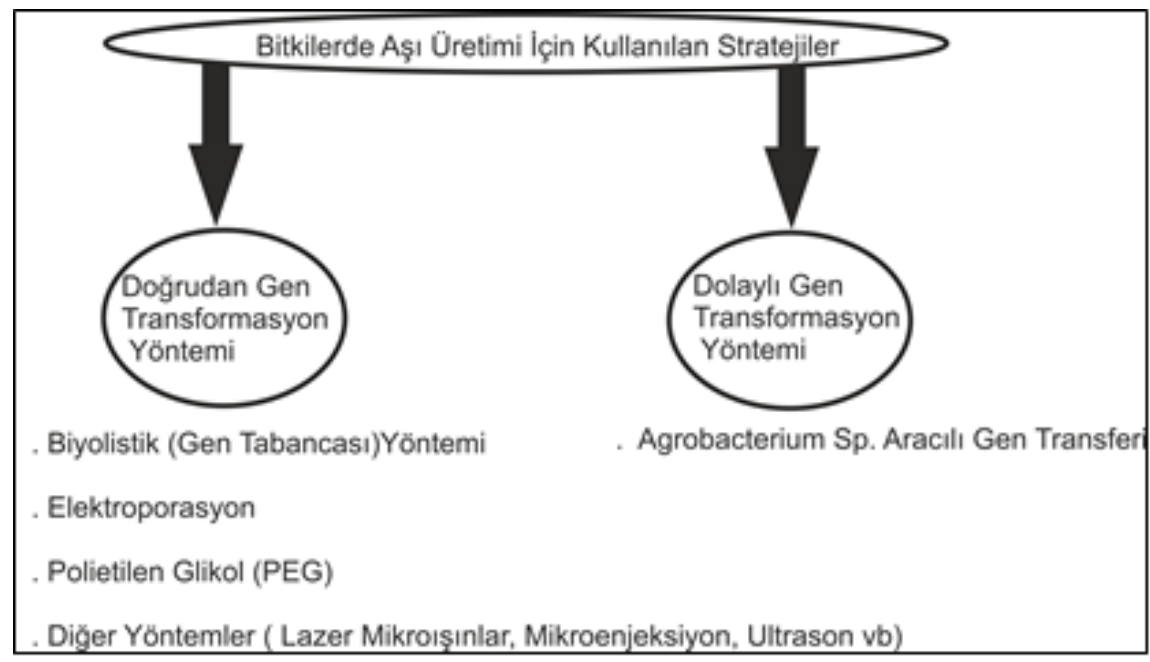

Şekil 1. Bitkilerde aşı üretimi için kullanılan stratejilere genel bakış

Biyolistik yöntemi, yaygın kullanılan diğer adlarıyla gen tabancası veya mikro mermi bombardımanı yöntemi, aşı antijeninin kodlanmasını sağlayacak gen dizisinin bitki hücrelerine doğrudan dahil edilmesini temel alan en yaygın ve vektörden bağımsız bir yöntemdir. $\mathrm{Bu}$ yöntemle çekirdek veya kloroplasta doğrudan transformasyon sağlanabilir [38]. Çekirdek transformasyonu, istenen genin homolog olmayan rekombinasyon yoluyla entegre edilmesiyle gerçekleştirilmektedir. Ancak, ekspresyon seviyesinin düşük olması sebebi ile aşı üretiminde kullanılabilmesi için yüksek miktarda bitkisel doku üretimini gerektirir. Kloroplast transformasyonu ise çekirdek transformasyonuna kıyasla; gen susturma etkisini ortadan kaldırma yeteneği, istenilen proteinin veya antijenin yüksek kopya sayısında ifadesini sağlaması (Şekil 2) ve birden fazla geni ifade etme potansiyeli, hızlı ve düşük maliyetli bir üretim sağlaması sebepleri ile bitkisel türevli aşı üretiminde tercih edilmektedir. Aynı zamanda kloroplastlarda sağlanan yüksek antijen verimi, aşılama için gerekli bitki materyali miktarını azaltmakta, dondurularak kurutulmuş materyalin kapsüllenmesini veya hap oluşumunu kolaylaştırmaktadır [39]. Literatürde kolera, Lyme hastalığ 1 , şarbon, tetanoz, veba, kuduz, rotavirüs ve köpek parvovirüs (CPV) aşılarının üretimi için bu yöntemin kullanıldığı ve hayvan modelinde immünizasyonunun sağlandığı bitkisel türevli aşı üretim çalışmaları bulunmaktadır [40, 41].
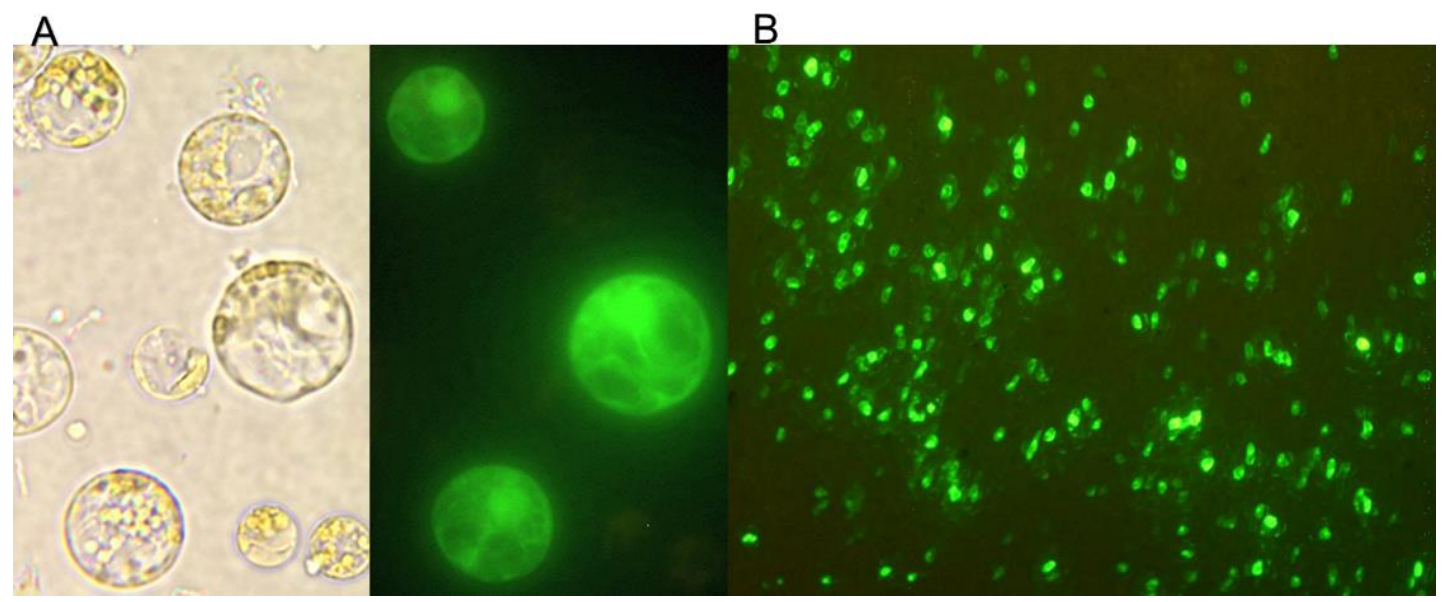

Şekil 2. (A) Doğrudan çekirdeğe aktarılmış yeşil floresans proteinleri (GFP) ile elektroporasyon yapılmış mısır protoplastları (B) Kloroplasta aktarılmış Lima fasulyesinde partikül bombardımanı aracılı̆̆ıla yeşil floresans proteinlerinin (GFP) ifadesi [42]. Kloroplastların (B) çekirdeğe (A) kıyasla daha yüksek seviyede ifade olmasının sebebi, bitki hücresindeki yüksek kopya sayısı sebebiyle hedefin birden fazla geni ifade edebilme potansiyelinden ileri gelmektedir. 
Agrobacterium sp. aracılı gen transferi yönteminde, bitki hücrelerini doğal olarak enfekte eden ve bitki genomuna entegre olabilme potansiyeline sahip bakteriler kullanılır [43]. Agrobacterium sp. pek çok çift çenekli bitki türünde taç gal (crown gall) hastalığına neden olan bir toprak bakterisidir. Bakteri T-DNA'sı, Ti plazmid (tümör uyarıcı) olarak adlandırılan bir ekstrakromozomal plazmit üzerinde taşınır ve bitki genomik DNA'sına entegre olur. 200 kb uzunluğunda olan Ti plazmitinde eşsiz bir restriksiyon bölgesinin mevcut olmaması bitkiye aktarılmak istenilen genin (rekombinant bir antijeni kodlayan gen dizisi) doğrudan Ti plazmit içerisine konumlandırılabilmesini sınırlamaktadır. Bundan dolayı plazmite yeni DNA'nınentegrasyonu için stratejiler geliştirilmiştir: İkili vektör stratejisi, T-DNA'nın fiziksel olarak Ti plazmitinin tümünü bağlaması gerekmediği gözlemlerine dayanır. Nispeten küçük bir molekül üzerindeki T-DNA içeren ikili plazmit sistemi ve normal şekildeki plazmitin tümü, bitki hücrelerini transforme etmede etkilidir. Gerçekte bazı A. tumefaciens soyları ve akraba agrobakteriler, doğal olarak ikili plazmit sistemine sahiptirler. T-DNA'nın plazmiti eşsiz restriksiyon yerlerine sahip olacak ve standart teknikleri kullanarak manipüle edilecek kadar küçüktür [42]. Diğer bir strateji ise, koentegrasyon sistemidir. Bu sistemde ise, E. coli vektörlerine dayalı, fakat ufak bir T-DNA bölgesi taşıyan tamamıyla yeni bir plazmit kullanılmaktadır. Yeni molekül ile Ti plazmit arasındaki homoloji, eğer ikisi A. tumefaciens hücresinde bulunursa, rekombinasyon pBR plazmitini T-DNA bölgesine entegre edebilir anlamına gelir. Klonlanacak gen bundan dolayı pBR plazmiti üzerinde eşsiz bir restriksiyon yerine sokulup, A. tumefaciens hücrelerine aktarılır ve doğal rekombinasyon işlemi T-DNA'sına yeni genin entegre olması için kendi haline bırakılır. Bitkilerin enfeksiyonu bitki kromozomlarına, T-DNA'sının tümüyle birlikte, yeni genin sokulmasını sağlar [44].

Agrobacterium aracılı transformasyon çalışmalarında, bitkinin doğal patojeni olan virüsü modifiye edilerek vektör görevi görmektedir. Rekombinant virüs, bitkilerde viral enfeksiyon sırasında replikasyon aktivitesinin bir yan ürünü olarak istenen proteini veya peptidi ifade etmektedir. Yöntemin avantajları arasında, enfeksiyondan kısa bir süre sonra yüksek seviyede protein/antijen ekspresyonu, viral partikül yüzeyinde çoklu antijen kopyaları oluşturma kolaylığ yer almaktadır. Hepatit B, HPV(insan papiloma virüsü), H1N1 ( influenza), kuş gribi, HIV gibi birçok hastalığa karşı bitkisel türevli aşı üretim çalışmalarında yöntemin başarı ile kullanıldığı ve antijen üretimini sağladığ1 görülmüştür (Tablo 1). Ancak, üretimi sağlanan antijenin aşı gibi farmasotik bir ürünün formülasyonunda kullanılabilmesi için bitki dokusundan saflaştırılma işleminin gerekliliği, rekombinant virüs ile enfekte olan bitkinin saflaştırma işlemi sırasında ölmesi ve yeniden kullanılamamasına neden olmaktadır. Bu sebeple enfeksiyon prosedürünün üretimde sürekliliği sağlamak için tekrar tekrar yapılması gereksinimini doğurmaktadır [45].

Bitkilerin doğal patojeni olan bazı RNA virüslerinin (tütün mozaik virüsü (TMV), patates virüsü X (PVX), yonca mozaik virüsü (AIMV), salatalık mozaik virüsü (CMV) ve börülce mozaik virüsü gibi tasarlanmış) ve DNA virüsü Geminivirüslerin bitki ekspresyon sistemi olarak beşeri ve veteriner aşı üretiminde kullanılabileceği düşünülmektedir [46]. Geminivirüslerle yapılan bir çalışmada $N$. benthamiana bitkisinde Ebola bağışıklık kompleksi (EIC) üretimi için kullanılmıştır. İnsan papilloma virüsü, influenza ve norovirüse karşı aşı üretmek amacı ile bitkisel sistemler kullanılmıştır. Bitki üretim platformunun hız ve uygulanabilirliği göz önüne alındığında, viral antijenlerin veya antiviral proteinlerin üretimine yönelik ani talebi karşılamak ve yüksek seviyelerde rekombinant proteinler üretmek için kullanılabilmesi durumu bir kez daha bitkisel kökenli aşıların önemini gözler önüne sermiştir [47]. Rekombinant ürünlerin bitki hücresi süspansiyon kültürü ile üretimi, geleneksel mikrobiyal veya memeli konakçı sistemlerine göre daha güvenilir olmaları, uygun üretim maliyetleri ve protein translasyonu sonrası modifikasyon kapasiteleri gibi pek çok avantaj sunmaktadır. Günümüzde, geçici ifade platformunun geliştirilmesiyle bitkilerde protein/antijen üretimi hızlı ve yüksek miktarlarda gerçekleştirilebilmektedir [48]. Bakteriyel ve memeli hücrelerine benzer şekilde heterolog protein üretimi, bütün bitkilerden ziyade bitki hücrelerinin ayrı ayrı süspansiyonu yapılarak da elde edilebilmektedir. Sıvı ortamda büyütülen hücre süspansiyonu, aseptik bir ortamda büyük ölçekli protein üretimi için biyoreaktörlerde ölçeklendirilebilmektedir. Genetik mühendisliğindeki ilerlemeler ve hücre kültürü ortamında ürünün proteolitik bozunması ve işlevsellik kaybının en aza indirilmesi dahil olmak üzere bitki hücreleri kullanılarak rekombinant protein ekspresyonundaki darboğazların anlaşılmasında önemli ilerlemeler kaydedilmiştir [49]. Konakçı bitki dokularında bazı aşıların üretim verimliliğinin arttırılması için kimyasal uyarıcı ve sonikasyon yöntemi gibi ek yöntemler uygulanmaktadır. Kimyasal uyarım ile DNA’nın alınımı bu yöntemlerden en yaygın kullanılandır. Bitki protoplastları tarafından DNA alımını hızlandırmak için en çok kullanılan kimyasal uyarıcı ise polietilen glikoldür (PEG). PEG, iyonik makromolekülleri (DNA'yı) çökelterek, DNA'nın endositoz yoluyla protoplastlara alımını teşvik eder ve böylece istenen genlerin geçici ifadesini mümkün kılar [50]. Bir diğer yöntem olan sonikasyon yöntemi ise, çözeltiyi karıştırmayı, çözünme oranını artırmayı ve çözünmüş gazları sıvıdan uzaklaştırmayı amaçlayan bir tekniktir [51]. Farmasötik uygulamalarda kullanılan rekombinant proteinlerin üretimi belirli kalite standartları gerektirir. Bitki ve bakteri yetiştirme, infiltrasyon, bitki hasadı, protein saflaştırma, formülasyon, bitmiş ürün kontrolleri vb üretimin uluslararası gerekliliklerinin yerine getirilebilmesi amacı ile İyi Üretim Uygulamaları (GMP) sertifikasyonuna sahip üretim tesisleri gereklidir [6]. Örneğin, patates yumrularında üretilen norovirüs kapsid protein aşısı, Arizona Eyalet Üniversitesi'nde geliştirilmiş ve Kentucky BioProcessing GMP (İyi İmalat Uygulamaları) fabrikasında üretilmiştir [52]. Japonya'da, Çeltik bazlı kolera aşısı, Tokyo Üniversitesi Tıp Bilimleri Enstitüsü'nde (IMSUT) geliştirilmiş ve IMSUT'taki GMP tesisinde üretilmiştir [53]. 


\section{Sonuç}

Bitkiler, farmasötik ve farmasötik olmayan ürünlerin üretimi için geleneksel ekspresyon sistemlerine göre hem ekonomik hem de teknik avantajlara sahiptir. Çekirdek, kloroplast ekspresyonu ve viral transfeksiyon sistemleri gibi farklı teknolojiler ile kısa sürede daha iyi üretim ve çeşitlendirilmiş ürün hedeflerini ele almalarını sağlayan benzersiz özelliklere sahiptir. Ancak antijen- bitki ekspresyon konağının uyumu ve özellikle dozaj tutarlılığı, yöntemin sınırlayıcı faktörleri arasında yer almaktadır. Üretilen dozaj tek düzeliği, bitkilerin büyüklüğü ve olgunluğuna bağlı olarak, meyveden meyveye ve nesilden nesile değişiklik gösterebileceğinden, günümüzde üretimde, bitkisel dokudan proteinin izole edilip saflaştırıldığ 1 yöntemler kullanılmaktadır [54]. Bitkisel türevli üretim yöntemi ile aspirde insülin (SemBioSys, Kanada), arpada büyüme faktörü (ORF Genetics, İzlanda), havuçta taligluceraz alfa (Protalix BioTherapeutics, İsrail), tütünde kuş gribi (Medicago, Kanada) ve Ebola aşısı vb. gibi aşıların geliştirildiği çok sayıda araştırma mevcuttur [55].

\section{Kaynaklar}

[1] Hamborsky, J., Kroger A., Wolfe S, eds. 13th ed. (2015) Centers for Disease Control and Prevention. Epidemiology and Prevention of Vaccine-Preventable Diseases. Washington D.C. Public Health Foundation. $1,4$.

[2] Wang, H., Dwyer-Lindgren L., Lofgren, K. T., Rajaratnam, J. K., Marcus, J. R., Levin-Rector, A., Levitz, C. E., Lopez, A. D., \& Murray, C. J. (2012). Age-specific and sex-specific mortality in 187 countries, 1970-2010: a systematic analysis for the Global Burden of Disease Study 2010. The Lancet, 380(9859), 2071-2094.

[3] Ohmit, S. E., Victor, J. C. , Rotthoff, J. R., Teich, E. R., Truscon, R. K., Baum, L. L., Rangarajan, B., Newton, D. W., Boulton, M. L., \& Monto, A. S. (2006). Prevention of antigenically drifted influenza by inactivated and live attenuated vaccines. New England Journal of Medicine, 355(24), 2513-2522.

[4] Moghaddam, A., Olszewska, W., Wang, B., Tregoning, J. S., Helson, R., Sattentau, Q. J., \& P. J. Openshaw (2006). A potential molecular mechanism for hypersensitivity caused by formalin-inactivated vaccines. Nature Medicine, 12(8), 905-907.

[5] Lobato, F. C., Lima, C. G., Assis, R. A., Pires, P. S., Silva, R. O., Salvarani, F. M., Carmo, A. O., Contigli, C., \& Kalapothakis, E., (2010). Potency against enterotoxemia of a recombinant Clostridium perfringens type D epsilon toxoid in ruminants. Vaccine, 28(38), 6125-6127.

[6] Takeyama, N., Kiyono, H. \& Yuki, Y. (2015). Plant-based vaccines for animals and humans: recent advances in technology and clinical trials. Therapeutic Advances in Vaccines. 3(5-6), 139-154.

[7] Hefferon, K. L. (2010). The mucosal immune response to plant-derived vaccines. Pharmaceutical Research, 27(10), 2040-2042.

[8] Schillberg, S., Raven N., Spiegel, H., Rasche, S. \& Buntru, M. (2019). Critical analysis of the commercial potential of plants for the production of recombinant proteins. Frontiers in Plant Science, 10, 720.

[9] Daniell, H., Rai, V. \& Xiao, Y. (2019). Cold chain and virus- free oral polio booster vaccine made in lettuce chloroplasts confers protection against all three poliovirus serotypes. Plant Biotechnology Journal, 17(7), 1357 1368.

[10] Mason, H. S., Lam, D. \& Arntzen, C. J. (1992). Expression of hepatitis B surface antigen in transgenic plants. Proceedings of the National Academy of Sciences, 89(24), 11745-11749.

[11] Tuboly, T., Yu, W., Bailey, A., Degrandis, S., Du, S., Erickson, L. \& Nagy, E. (2000). Immunogenicity of porcine transmissible gastroenteritis virus spike protein expressed in plants. Vaccine, 18(19), 2023-2028.

[12] Khandelwal, A., Sita, G. L., \& Shaila, M. (2003). Oral immunization of cattle with hemagglutinin protein of rinderpest virus expressed in transgenic peanut induces specific immune responses. Vaccine, 21(23), 3282-3289.

[13] Filgueira, D. P., Zamorano, P. I., Dominguez, M., Taboga, O., Zajac, M. D. M., Puntel, M., Romera, S. A., Morris, T. J., Borca, M., \& Sadir, A. M. (2003). Bovine herpes virus gD protein produced in plants using a recombinant tobacco mosaic virus (TMV) vector possesses authentic antigenicity. Vaccine, 21(27-30), 42014209.

[14] Varsani, A., Williamson, A. L., Rose, R. C., Jaffer, M., \& Rybicki, E. P. (2003). Expression of Human papillomavirus type 16 major capsid protein in transgenic Nicotiana tabacum cv. Xanthi. Archives of Virology, 148(9), 1771-1786.

[15] Lamphear, B. J., Jilka, J. M., Kesl, L., Welter, M., Howard, J. A., \& Streatfield, S. J. (2004). A corn-based delivery system for animal vaccines: an oral transmissible gastroenteritis virus vaccine boosts lactogenic immunity in swine. Vaccine, 22(19), 2420-2424.

[16] Zhou, J.-Y., Cheng, L.Q., Zheng, X.J., Wu, J.X., Shang, S.B., Wang, J.Y., \& Chen, J.G. (2004). Generation of the transgenic potato expressing full-length spike protein of infectious bronchitis virus. Journal of Biotechnology, 111(2), 121-130. 
[17] Koya, V., Moayeri, M., Leppla, S. H., \& Danielli, H. (2005). Plant-based vaccine: mice immunized with chloroplast-derived anthrax protective antigen survive anthrax lethal toxin challenge. Infection and Immunity, 73(12), 8266-8274.

[18] Thanavala, Y., Mahoney, M., Pal, S., Scott, A., Richter, L., Natarajan, N., Goodwin, P., Arntzen, C. J. \& Mason, H. S. (2005). Immunogenicity in humans of an edible vaccine for hepatitis B. Proceedings of the National Academy of Sciences, 102(9), 3378-3382.

[19] Guerrero-Andrade, O., Loza-Rubio, E., Olivera-Flores, T., Fehérvári-Bone, T., \& Gómez-Lim, M. A. (2006). Expression of the Newcastle disease virus fusion protein in transgenic maize and immunological studies. Transgenic Research, 15(4), 455-463.

[20] Joensuu, J., Verdonck, F., Ehrström, A., Peltola, M., Siljander-Rasi, H., Nuutila, A.M., Oksman-Caldentey, K.M., Teeri, T., Cox, E., \& B. Goddeeris (2006). F4 (K88) fimbrial adhesin FaeG expressed in alfalfa reduces F4+ enterotoxigenic Escherichia coli excretion in weaned piglets. Vaccine, 24(13), 2387-2394.

[21] Kohl, T., Hitzeroth, I., Stewart, D., Varsani, A., Govan, V., Christensen, N., Williamson, A.L. \& Rybicki, E. (2006). Plant-produced cottontail rabbit papillomavirus L1 protein protects against tumor challenge: a proof-ofconcept study. Clinical and Vaccine Immunology, 13(8), 845-853.

[22] Wu, J., Yu, L., Li, L., Hu, J., Zhou, J., \& Zhou, X. (2007). Oral immunization with transgenic rice seeds expressing VP2 protein of infectious bursal disease virus induces protective immune responses in chickens. Plant Biotechnology Journal, 5(5), 570-578.

[23] Huang, Z., LePore, K., Elkin, G., Thanavala, Y., \& Mason, H. S. (2008). High- yield rapid production of hepatitis B surface antigen in plant leaf by a viral expression system. Plant Biotechnology Journal, 6(2), 202209.

[24] D’Aoust, M. A., Lavoie, P. O., Couture, M. M. J., Trépanier, S., Guay, J. M., Dargis, M., Mongrand, S., Landry, N., Ward, B. J. \& Vézina, L. P. (2008). Influenza virus- like particles produced by transient expression in Nicotiana benthamiana induce a protective immune response against a lethal viral challenge in mice. Plant Biotechnology Journal, 6(9), 930-940.

[25] Rosales-Mendoza, S., Soria-Guerra, R. E., López-Revilla, R., Moreno-Fierros, L., \& Alpuche-Solís, Á. G. (2008). Ingestion of transgenic carrots expressing the Escherichia coli heat-labile enterotoxin B subunit protects mice against cholera toxin challenge. Plant Cell Reports, 27(1), 79-84.

[26] Santi, L., Batchelor, L., Huang, Z., Hjelm, B., Kilbourne, J., Arntzen, C. J., Chen, Q., \& Mason, H. S. (2008). An efficient plant viral expression system generating orally immunogenic Norwalk virus-like particles. Vaccine, 26(15), 1846-1854.

[27] Kalthoff, D., Giritch, A., Geisler, K., Bettmann, U., Klimyuk, V., Hehnen, H.R., Gleba, Y. \& Beer, M. (2010). Immunization with plant-expressed hemagglutinin protects chickens from lethal highly pathogenic avian influenza virus H5N1 challenge infection. Journal of Virology, 84(22), 12002-12010.

[28] Shoji, Y., Farrance, C. E., Bautista, J., Bi, H., Musiychuk, K., Horsey, A., Park, H., Jaje, J., Green, B. J., \& Shamloul, M. (2012). A plant- based system for rapid production of influenza vaccine antigens. Influenza and Other Respiratory Viruses, 6(3), 204-210.

[29] Firsov, A., Tarasenko, I., Mitiouchkina, T., Ismailova, N., Shaloiko, L., Vainstein, A. \& Dolgov, S. (2015). High-yield expression of M2e peptide of avian influenza virus H5N1 in transgenic duckweed plants. Molecular Biotechnology, 57(7), 653-661.

[30] Vaquero, C., Sack, M., Chandler, J., Drossard, J., Schuster, F., Monecke, M., Schillberg, S. \& Fischer, R. (1999). Transient expression of a tumor-specific single-chain fragment and a chimeric antibody in tobacco leaves. Proceedings of the National Academy of Sciences, 96(20), 11128-11133.

[31] Torres, E., Vaquero, C., Nicholson, L., Sack, M., Stöger, E., Drossard, J., Christou, P., Fischer, R. \& Perrin, Y. (1999). Rice cell culture as an alternative production system for functional diagnostic and therapeutic antibodies. Transgenic Research, 8(6), 441-449.

[32] Stöger, E., Vaquero, C., Torres, E., Sack, M., Nicholson, L., Drossard, J., Williams, S., Keen, D., Perrin, Y. \& Christou P. (2000). Cereal crops as viable production and storage systems for pharmaceutical scFv antibodies. Plant Molecular Biology, 42(4), 583-590.

[33] Brodzik, R., Glogowska, M., Bandurska, K., Okulicz, M., Deka, D., Ko, K., Van der Linden J., Leusen, J. H., Pogrebnyak, N. \& Golovkin, M. (2006). Plant-derived anti-Lewis Y mAb exhibits biological activities for efficient immunotherapy against human cancer cells. Proceedings of the National Academy of Sciences, 103(23), 8804-8809.

[34] Floss, D. M., Sack, M., Stadlmann, J., Rademacher, T., Scheller, J., Stöger, E., Fischer, R. \& Conrad, U. (2008). Biochemical and functional characterization of anti- HIV antibody-ELP fusion proteins from transgenic plants. Plant Biotechnology Journal, 6(4), 379-391. 
[35] Huang, Z., Phoolcharoen, W., Lai, H., Piensook, K., Cardineau, G., Zeitlin, L., Whaley, K. J., Arntzen, C. J., Mason, H. S. \& Chen, Q. (2010). High- level rapid production of full- size monoclonal antibodies in plants by a single- vector DNA replicon system. Biotechnology and Bioengineering, 106(1), 9-17.

[36] Lai, H., He, J., Engle, M., Diamond, M. S. \& Chen, Q. (2012). Robust production of virus- like particles and monoclonal antibodies with geminiviral replicon vectors in lettuce. Plant Biotechnology Journal, 10(1), 95-104.

[37] Laere, E., Ling, A. P. K., Wong, Y. P., Koh, R. Y., Mohd Lila, M. A. \& Hussein, S. (2016). Plant-Based Vaccines: Production and Challenges. Journal of Botany. Article ID 4928637

[38] Naderi, S. \& Fakheri, B. (2015). Overview of plant-based vaccines. Research Journal of Fisheries and Hydrobiology, 10(10), 275-289.

[39] Molina, A., Hervás- Stubbs, S., Daniell, H., Mingo- Castel, A. M. \& Veramendi, J. (2004). High- yield expression of a viral peptide animal vaccine in transgenic tobacco chloroplasts. Plant Biotechnology Journal, 2(2), 141-153.

[40] Kanagaraj, A. P., Verma, D. \& Daniell, H. (2011). Expression of dengue-3 premembrane and envelope polyprotein in lettuce chloroplasts. Plant Molecular Biology, 76(3-5), 323.

[41] Loza-Rubio, E., Rojas, E., Gomez, L., Olivera, M. \& Gomez-Lim, M. (2008). Development of an edible rabies vaccine in maize using the Vnukovo strain. Developments in Biologicals, 131, 477-482.

[42] Stewart Jr, C. N. (2016). Plant biotechnology and genetics: principles, techniques, and applications, John Wiley \& Sons. Inc Publication, 10, 245-254.

[43] Chen, Q. \& H. Lai (2015). Gene delivery into plant cells for recombinant protein production. BioMed Research International, Article ID 932161,

[44] Liu, W., Yuan, J. S. \& Stewart Jr., C. N. (2013). Advanced genetic tools for plant biotechnology. Nature Reviews Genetics, 14(11), 781-793.

[45] Yu, J. \& Langridge, W. H. (2000). Novel approaches to oral vaccines: delivery of antigens by edible plants. Current Infectious Disease Reports, 2(1), 73-77.

[46] Hefferon, K. L. (2014). DNA virus vectors for vaccine production in plants: spotlight on geminiviruses. Vaccines, 2(3), 642-653.

[47] Shanmugaraj, B., Siriwattananon, K., Wangkanont, K. \& W. Phoolcharoen (2020). Perspectives on monoclonal antibody therapy as potential therapeutic intervention for Coronavirus disease-19 (COVID-19). Asian Pac J Allergy Immunol, 38(1), 10-18.

[48] Buyel, J. F. (2018). Plant molecular farming-Integration and exploitation of side streams to achieve sustainable biomanufacturing. Frontiers in Plant Science, 9, 1893.

[49] Huang, T.K. \& McDonald, K. A. (2009). Bioreactor engineering for recombinant protein production in plant cell suspension cultures. Biochemical Engineering Journal, 45(3), 168-184.

[50] Jeon, J. M., Ahn, N. Y., Son, B. H., Kim, C. Y., Han, C.D., Kim, G.D., Gal, S. W. \& Lee, S.H. (2007). Efficient transient expression and transformation of PEG-mediated gene uptake into mesophyll protoplasts of pepper (Capsicum annuum L.). Plant Cell, Tissue and Organ Culture, 88(2), 225-232.

[51] Santarem, E., Trick, H., Essig, J. \& Finer, J. (1998). Sonication-assisted Agrobacterium-mediated transformation of soybean immature cotyledons: optimization of transient expression. Plant Cell Reports, 17(10), 752-759.

[52] Tacket, C. O., Mason, H. S., Losonsky, G., Estes, M. K., Levine, M. M. \&. Arntzen, C. J (2000). Human immune responses to a novel Norwalk virus vaccine delivered in transgenic potatoes. The Journal of Infectious Diseases, 182(1), 302-305.

[53] Yuki, Y., Mejima, M., Kurokawa, S., Hiroiwa, T., Takahashi, Y., Tokuhara, D., Nochi, T., Katakai, Y., Kuroda, M. \& Takeyama, N. (2013). Induction of toxin- specific neutralizing immunity by molecularly uniform rice- based oral cholera toxin B subunit vaccine without plant- associated sugar modification. Plant Biotechnology Journal, 11(7), 799-808.

[54] Sharma, M. \& B. Sood (2011). A banana or a syringe: journey to edible vaccines. World Journal of Microbiology and Biotechnology, 27(3), 471-477.

[55] Faye, L. \& V. Gomord (2010). Success stories in molecular farming - a brief overview. Plant Biotechnology Journal, 8(5), 525-528. 